CRYSTALLOGRAPHIC COMMUNICATIONS

ISSN 2056-9890

Received 15 May 2020

Accepted 16 September 2020

Edited by G. Diaz de Delgado, Universidad de Los Andes, Venezuela

Keywords: methylpropanoate; metal-organic framework compounds; Cambridge Structural Database; crystal structure.

CCDC reference: 2032320

Supporting information: this article has supporting information at journals.iucr.org/e
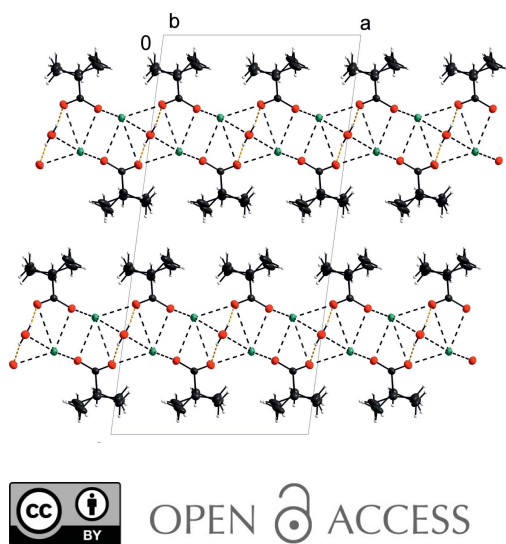

OPEN $\odot$ ACCESS

\section{Crystal structure of poly[ $\mu$-aqua-bis $\left(\mu_{3}-2-\right.$ methyl- propanoato- $\left.\kappa^{4} O: O, O^{\prime}: O^{\prime}\right)$ dipotassium]}

\author{
Jan Fábry* and Erika Samolová
}

Inst. of Physics of the Czech Academy of Sciences, Na Slovance 2, 18221 Praha 8, Czech Republic. *Correspondence e-mail: fabry@fzu.cz

The structure of the title compound, $\left[\mathrm{K}_{2}\left(\mathrm{C}_{4} \mathrm{H}_{7} \mathrm{O}_{2}\right)_{2}\left(\mathrm{H}_{2} \mathrm{O}\right)\right]_{n}$, is composed of stacked sandwiches, which are formed by cation-oxygen bilayers surrounded by methylethyl hydrophobic chains. These sandwiches are held together by van der Waals interactions between the methylethyl groups. The methylethyl groups are disordered over two positions with occupancies 0.801 (3):0.199 (3). The potassium cations are coordinated by seven $\mathrm{O}$ atoms, which form an irregular polyhedron. There is a water molecule, the oxygen atom of which is situated in a special position on a twofold axis (Wyckoff position 4e). The water $\mathrm{H}$ atoms are involved in $\mathrm{O}_{\text {water }}-\mathrm{H} \cdots \mathrm{O}_{\text {carboxyl }}$ hydrogen bonds of moderate strength. These hydrogen bonds are situated within the cation-oxygen, i.e. hydrophilic, bilayer.

\section{Chemical context}

The structures of simple alkali 2-methylpropanoates (isobutyrates) have not been determined so far (as shown by a search of the Cambridge Structural Database, version 5.41, update of November 2019; Groom et al., 2016) . In this context, 'simple' means a compound containing just one cationic species. The reason for this rather surprising fact may follow from the expected difficult crystallization (Mirnaya et al., 1991). Moreover, the phases of isobutyrate salts are supposedly prone to undergo phase transitions due to the ordering of voluminous hydrophobic methylethyl chains by analogy to the phase transitions observed in alkali propionates and 2-methylpropanoates (Ferloni et al., 1975).

The chemistry of water solutions and the corresponding solid phases of 2-methylpropanoates and other carboxylates where the number of carbon atoms is greater than two differs from that of formates and acetates. The structures and chemistry of the former compounds are also affected by hydration (Mirnaya et al., 1991). Hydration may take place because water molecules compete with the carboxylates in inclusion into the coordination sphere of the cations. Moreover, a rather tedious structure determination can be expected in alkanoates where the number of carbon atoms is greater than two because the organic chains tend to be positionally disordered and tend to exert large thermal agitation. This disorder, as well as the large displacement parameters, is related to the tendency to form different phases as pointed out above.

The structure determinations of 2-methylpropanoates as well as those of chemically related compounds with carboxylates other than the formates and acetates show that their structures share the same tendency for the separation of metal cations, carboxylate groups and sometimes water molecules on the one hand from the organic chains on the other. 
The former groups are hydrophilic while the latter are hydrophobic. The separation of these groups in these structures may be considered as an illustration of the alchemists' experience expressed by the slogan similis similibus solvuntur on a microstructural level. This separation also refers to solvate molecules and affects their orientation with regard to their hydrophilic and hydrophobic ends. The compound catena-[tetrakis $\left(\mu_{2}\right.$-isobutyrato- $\left.O, O, O^{\prime}\right)$ bis(isobutyrato- $O, O^{\prime}$ )triaquadicerium ethanol solvate] (refcode XALZAN; Malaestean et al., 2012) can serve as an example.

Thus, the intermolecular bonds in these structures can be divided into metal-oxygen bonds, $\mathrm{O}-\mathrm{H} \cdots \mathrm{O}$ hydrogen bonds and van der Waals bonds between the hydrophobic groups. The water molecules as well as the solvate molecules can be either coordinated to the cation or not while completing the hydrophilic part of the structures. At the same time, they are included into the hydrogen-bond pattern.

Correspondingly, the structures can be divided into the following classes (Table 1):

(i) Structures that are composed of clusters where the inner part is formed by hydrophilic parts while the outer skin is formed by hydrophobic groups.

(ii) Structures that are formed by columns, the interior of which is composed of the hydrophilic parts while the outer skin is hydrophobic.

(iii) Layered structures that are composed of stacked sandwiches formed by cation-oxygen bilayers surrounded by hydrophobic organic groups. These sandwiches are bonded by van der Waals forces.

In all of these structural types, water molecules can occur; examples are given in Table 1.

So far, the structures of 2-methylpropanoates (isobutyrates) have been reviewed. The motif of stacked layers, however, seems to be typical for simple alkali alkanoates $M^{+} \mathrm{C}_{n} \mathrm{H}_{2 n+1} \mathrm{COO}^{-}, n>2$, as follows from the known structures of $\mathrm{Li}\left(\mathrm{C}_{3} \mathrm{H}_{5} \mathrm{O}_{2}\right)$ (refcodes OMERUV, OMERUV01 and OMERUV02; Martínez Casado et al., 2009), and the recently determined series of structures of $\mathrm{Na}, \mathrm{K}, \mathrm{Rb}$ and $\mathrm{Cs}$ propanoates (Fábry \& Samolová, 2020), $\mathrm{Tl}\left(\mathrm{C}_{3} \mathrm{H}_{5} \mathrm{O}_{2}\right)$, catena[( $\mu_{2}$-propanoato)thallium(I)(propanoato)thallium(I)]

(WEWKAM; Martínez Casado et al., 2010) and further from the structures of potassium acrylate and potassium methacrylate (refcodes VOVWOV and VOVWAH, respectively; Heyman et al., 2020) as well as from the known structures with alkanoates with longer organic chains, e.g. potassium palmitate $\mathrm{KC}_{16} \mathrm{H}_{31} \mathrm{O}_{2}$ (KPALMA; Dumbleton \& Lomer, 1965).

Thus, the typical motif of separated hydrophobic and hydrophilic parts of the molecules can be generalized for carboxylates other than formates and acetates.

The physical properties of 2-methylpropanoates as well as other related carboxylates $\mathrm{C}_{n} \mathrm{H}_{2 n+1} \mathrm{COO}^{-}, n>2$, hinder possible applications of these compounds, although there are some exceptions such as lanthanide zinc butyrates or their analogues, which have been applied for the synthesis of lanthanide-zinc-oxygen nanoparticles (Boyle et al., 2010) or for gelation induced by ultrasound in presence of $\mathrm{ZnO}$ nanoparticles (Kotal et al., 2010).
Table 1

Overview of structural types observed in isobutyrates.

\begin{tabular}{|c|c|c|}
\hline Compound & Refcode & Reference \\
\hline \multicolumn{3}{|c|}{ Water-free clusters } \\
\hline 1 & OHOXUF & Malaestean et al. (2009) \\
\hline 2 & GEWFUL & Malaestean et al. (2013a) \\
\hline 3 & NAGQUI & Coker et al. (2004) \\
\hline \multicolumn{3}{|c|}{ Clusters interconnected by water molecules } \\
\hline 4 & NAGQUI & Coker et al. (2004) \\
\hline \multicolumn{3}{|c|}{ Water-free columns } \\
\hline 5 & PENJUN & Ilina et al. (1992) \\
\hline 6 & TAHXOR & Boyle et al. (2010) \\
\hline 7 & TAHXOR01 & Bierke \& Meyer (2008) \\
\hline 8 & TAHXOR02 & Kotal et al. (2010) \\
\hline \multicolumn{3}{|c|}{ Columns interconnected by water molecules } \\
\hline 9 & MECVAU & Skelton \& Deacon (2017) \\
\hline 10 & XALZAN & Malaestean et al. (2012) \\
\hline \multicolumn{3}{|c|}{ Water-free layered structures } \\
\hline 11 & KELKOE & Skelton \& Deacon (2017) \\
\hline 12 & LUHGOK & Yuranov \& Dunaeva (1989) \\
\hline \multicolumn{3}{|c|}{ Structures with layers interconnected by water molecules } \\
\hline 13 & VIQTOG & Malaestean et al. (2013b) \\
\hline 14 & POSCIJ & Troyanov et al. (1993) \\
\hline 15 & SAJMUO & Fischer et al. (2017) \\
\hline
\end{tabular}

Compound names, 1: bis $\left(\mu_{4}\right.$-oxo $)$ dodecakis $\left(\mu_{3}\right.$-isobutyrato $)$ hexakis $\left(\mu_{2}\right.$-isobutyrato $)$ bis(isobutyric acid)-bis(propanol)-octa-manganese(II)-di-manganese(III) dihydrate; 2: hexakis $\left(\mu_{3}\right.$-isobutyrato)hexakis $\left(\mu_{2}\right.$-isobutyrato)hexakis(2-methylpropanoic acid)hexamanganese; 3: hexakis[bis( $\mu_{2}$-2-methylpropanoato)(2-methylpropanoic acid)magnesium]; 4: bis $\left(\mu_{4}\right.$-oxo $)$ dodecakis $\left(\mu_{3}\right.$-isobutyrato $)$ hexakis $\left(\mu_{2}\right.$-isobutyrato $)$ bis(isobutyric acid)bis(propanol)octamanganese(II)dimanganese(III) propanol solvate; 5: bis[ $\left[\left(\mu_{3}-\right.\right.$ isobutyrylato- $\left.O, O^{\prime}\right)\left(\mu_{2}\right.$-isobutyrylato)copper(II)]; 6: catena-[tetrakis $\left(\mu_{2}\right.$-2-methylpropanoato)dizinc]; 7: catena-[tetrakis $\left(\mu_{2}\right.$-2-methylpropanoato)dizinc]; 8: catena-[tetrakis $\left(\mu_{2^{-}}\right.$ 2-methylpropanoato)dizinc); 9: catena-[tetrakis( $\mu$-2-methylpropanoato)bis(2-methylpropanoato)triaquadilanthanum(III) hydrate; 10: catena-[tetrakis $\left(\mu_{2}\right.$-isobutyrato$\left.O, O, O^{\prime}\right)$ bis(isobutyrato- $\left.O, O^{\prime}\right)$ triaquadicerium ethanol solvate]; 11: catena-[hexakis $(\mu-$ methylpropanoato)dilutetium]; 12: diaquabis(isobutyrato)dioxouranium(VI); 13: catena[( $\mu_{2}$-2-methylpropanoato)(2-methylpropanoato)triaquamagnesium monohydrate]; 14: catena-[hexakis $\left(\mu_{2}\right.$-isobutyrato)aquadierbium monohydrate]; 15: catena-[bis $(\mu$-2-methylpropanoato $)(\mu$-aqua)cobalt(II) monohydrate].

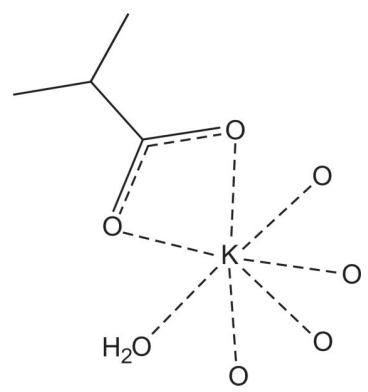

The aim of the present study was the preparation of potassium 2-methylpropanoate in order to fill the gap in the knowledge of these structures. Moreover, it was even more attractive to compare the sodium and potassium propanoate structures (Fábry \& Samolová, 2020) in which the methyl groups are situated in two positions related by rotation of $180^{\circ}$ because such a positional disorder mimics the arrangement of both methylethyl chains in 2-methylpropanoates by the demand for space. However, a crystal of a hydrated phase has been obtained, the structure of which is reported here. Still, the authors believe that this reported structure determination adds a piece of knowledge that could be helpful in under- 
Table 2

Selected bond lengths $(\AA)$.

\begin{tabular}{llll}
\hline $\mathrm{K} 1-\mathrm{O} 1$ & $3.1113(13)$ & $\mathrm{K} 1-\mathrm{O} 2^{\mathrm{iii}}$ & $2.7330(12)$ \\
$\mathrm{K} 1-\mathrm{O} 1^{\mathrm{i}}$ & $2.6951(14)$ & $\mathrm{K} 1-\mathrm{O} 3^{\mathrm{iv}}$ & $3.3351(13)$ \\
$\mathrm{K} 1-\mathrm{O} 2$ & $2.8056(13)$ & $\mathrm{K} 1-\mathrm{O} 3$ & $2.7693(12)$ \\
$\mathrm{K} 1-\mathrm{O} 2^{\mathrm{ii}}$ & $2.7360(12)$ & & \\
\hline \multicolumn{5}{l}{ Symmetry codes: } & (i) $-x+1, y,-z+\frac{1}{2} ;$ & (ii) $-x+\frac{3}{2}, y-\frac{1}{2},-z+\frac{1}{2} ;$ & (iii) \\
$-x+\frac{3}{2}, y+\frac{1}{2},-z+\frac{1}{2} ;$ (iv) $x, y-1, z$. &
\end{tabular}

standing the structural features in simple alkali carboxylates with $\mathrm{C}_{n} \mathrm{H}_{2 n+1} \mathrm{COO}^{-}, n>2$, and related structures.

\section{Structural commentary}

The structural unit of the title compound is shown in Fig. 1, which shows that the central cation is surrounded by seven oxygen atoms up to $\sim 3.33 \AA$. All of the oxygens stem from the carboxylates except for the atom $\mathrm{O} 3$, which is a part of the coordinated water molecule. The $\mathrm{K}-\mathrm{O}$ bond distances are listed in Table 2. Five of them, i.e. $\mathrm{O} 2, \mathrm{O} 2^{\mathrm{ii}}, \mathrm{O} 2^{\mathrm{iii}}, \mathrm{O} 3$ and $\mathrm{O} 3^{\mathrm{iv}}$, form a tetragonal pyramid with $\mathrm{O} 2$ as its apex. Atoms $\mathrm{O} 1$ and $\mathrm{O} 1^{\mathrm{i}}$ complete the coordination polyhedron [symmetry codes: (i) $1-x, y, \frac{1}{2}-z$; (ii) $\frac{3}{2}-x,-\frac{1}{2}+y, \frac{1}{2}-z$; (iii) $\frac{3}{2}-x, \frac{1}{2}+y, \frac{1}{2}-z$; (iv) $x,-1+y, z$.) It is also worth mentioning that the distances between the cation and the oxygen atoms belonging to the same carboxylate are quite different: $\mathrm{K} 1-\mathrm{O} 1=3.1113$ (13) $\AA$ and $\mathrm{K} 1-\mathrm{O} 2=2.8056$ (13) $\AA$.

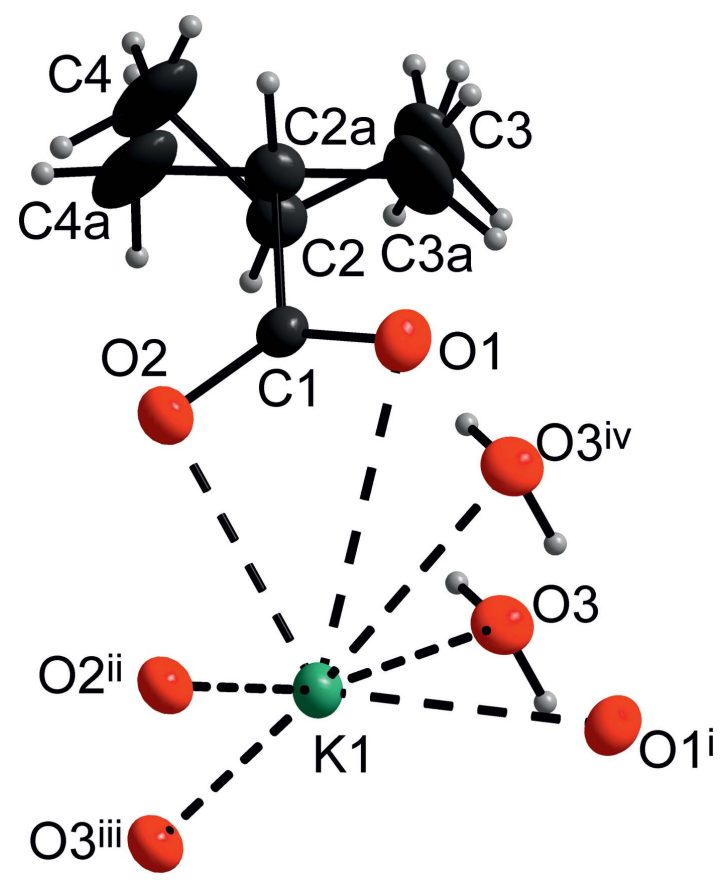

Figure 1

A view of the structural motif in the title compound (DIAMOND; Brandenburg, 2005): Displacement ellipsoids are shown at the $30 \%$ probability level. $\mathrm{K}, \mathrm{O}, \mathrm{C}$ and water $\mathrm{H}$ atoms are shown as green, red, black ellipsoids as well as gray spheres, respectively. Symmetry codes: (i) $1-x, y, \frac{1}{2}-z$; (ii) $\frac{3}{2}-x,-\frac{1}{2}+y, \frac{1}{2}-z$; (iii) $\frac{3}{2}-x, \frac{1}{2}+y, \frac{1}{2}-z$; (iv) $x,-1+y$,
Table 3

Hydrogen-bond geometry $\left(\AA,^{\circ}\right)$.

\begin{tabular}{lllll}
\hline$D-\mathrm{H} \cdots A$ & $D-\mathrm{H}$ & $\mathrm{H} \cdots A$ & $D \cdots A$ & $D-\mathrm{H} \cdots A$ \\
\hline $\mathrm{O}-\mathrm{H} 1 \mathrm{O} 3 \cdots \mathrm{O}^{\mathrm{v}}$ & $0.83(2)$ & $1.92(2)$ & $2.7358(17)$ & $167(2)$ \\
$\mathrm{O}^{\mathrm{v}-\mathrm{H} 1 \mathrm{O} 3} \cdots \mathrm{O}^{\mathrm{vi}}$ & $0.83(2)$ & $1.92(2)$ & $2.7358(17)$ & $167(2)$ \\
\hline
\end{tabular}

Symmetry codes: (i) $-x+1, y,-z+\frac{1}{2}$; (v) $x, y+1, z$; (vi) $-x+1, y+1,-z+\frac{1}{2}$.

\section{Supramolecular features}

The prominent feature of the title structure is the presence of an oxygen-metal bilayer, which is surrounded by methylethyl chains on both sides (Fig. 2). This bilayer is composed of the cations and the oxygen atoms.

Table 3 lists a pair of symmetry-equivalent $\mathrm{O}_{\text {water }}-$ $\mathrm{H} \cdot \mathrm{O}_{\text {carboxylate }}$ hydrogen bonds of moderate strength (Gilli \& Gilli, 2009). These hydrogen bonds take place within the cation-oxygen bilayer (Fig. 2). Interestingly, the water hydrogen atoms, supposedly positively charged, are directed towards the more distant cation $\mathrm{K} 1\left[\mathrm{H} 1 O 3 \cdots \mathrm{K} 1^{\mathrm{v}}\right.$ and $\mathrm{H} 1 O 3^{\mathrm{i}} \cdots \mathrm{K} 1^{\mathrm{v}}=3.033(19)$ and 3.01 (2) $\AA$, respectively, see Fig. 3 and its caption]. This means that the positive-charge interaction diminishes a cohesive weak interaction $\mathrm{O} 3 \cdots \mathrm{K} 1^{\mathrm{v}}$, the bond valence of which is 0.0385 (1) (Brese \& O'Keeffe, 1991). Other cohesive hydrogen-bonding interactions are listed in Table 3.

As stated above, methylethyl chains surround the hydrophilic inner bilayer on both sides. The packing of these sandwiches forms the title structure. The sandwiches are held together by van der Waals forces. Table 4 lists these weak interactions. Their distances are about the same as those in dicalcium barium hexakis(propanoate) $\mathrm{Ca}_{2} \mathrm{Ba}\left(\mathrm{C}_{3} \mathrm{H}_{5} \mathrm{O}_{2}\right)_{6}$

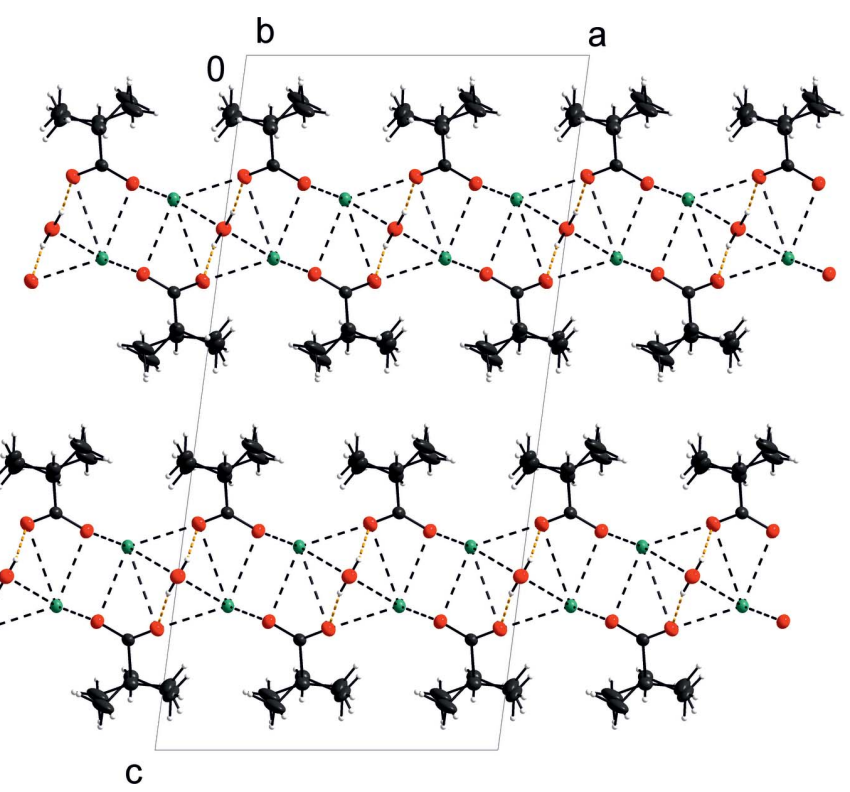

Figure 2

The packing of the molecules in the title compound (DIAMOND; Brandenburg, 2005) viewed along the $b$ axis. Displacement ellipsoids are shown at the $30 \%$ probability level. The colours are assigned to the atoms are as in Fig. 1. 
Table 4

$\mathrm{C}_{\text {methylene }}-\mathrm{C}_{\text {methyl }}$ and $\mathrm{C}_{\text {methyl }}-\mathrm{C}_{\text {methyl }}$ intermolecular distances $(\AA)$ in the title structure of up to $4.5 \AA$.

$\mathrm{C} 2, \mathrm{C} 2 a$ correspond to the methylene carbon atoms while $\mathrm{C} 3, \mathrm{C} 3 a$ and $\mathrm{C} 4, \mathrm{C} 4 a$ correspond to methyl atoms.

\begin{tabular}{llll}
\hline $\mathrm{C} 2 \cdots \mathrm{C} 4^{\mathrm{v}}$ & $4.251(6)$ & $\mathrm{C} 3 \cdots \mathrm{C} 4^{\mathrm{vi}}$ & $3.992(6)$ \\
$\mathrm{C} 3 \cdots \mathrm{C} 4^{\mathrm{viii}}$ & $4.136(6)$ & $\mathrm{C} 4 \cdots \mathrm{C} 4^{\mathrm{ix}}$ & $3.984(5)$ \\
$\mathrm{C} 3 a \cdots \mathrm{C} 4 a^{\mathrm{vii}}$ & $4.17(2)$ & $\mathrm{C} 3 a \cdots \mathrm{C} 4 a^{\mathrm{vi}}$ & $4.25(2)$ \\
$\mathrm{C} 4 a \cdots \mathrm{C} 4 a^{\mathrm{ix}}$ & $4.31(2)$ & $\mathrm{C} 2 a \cdots \mathrm{C} 3 a^{x}$ & $3.97(2)$ \\
$\mathrm{C} 2 a \cdots \mathrm{C} 4 a^{x}$ & $3.884(19)$ & $\mathrm{C} 2 \cdots \mathrm{C} 2 a^{\mathrm{v}}$ & $3.960(10)$ \\
$\mathrm{C} 2 \cdots \mathrm{C} 4 a^{x}$ & $4.479(16)$ & $\mathrm{C} 3 \cdots \mathrm{C} 2 a^{\mathrm{v}}$ & $4.128(11)$ \\
$\mathrm{C} 3 \cdots \mathrm{C} 3 a^{x}$ & $4.44(2)$ & $\mathrm{C} 3 \cdots \mathrm{C} 4 a^{\mathrm{vii}}$ & $4.000(15)$ \\
$\mathrm{C} 3 \cdots \mathrm{C} 4 a^{\mathrm{vi}}$ & $4.207(15)$ & $\mathrm{C} 4 \cdots \mathrm{C} 3 a^{x}$ & $4.48(2)$ \\
$\mathrm{C} 4 \cdots \mathrm{C} 3 a^{\mathrm{xi}}$ & $4.087(14)$ & $\mathrm{C} 4 \cdots \mathrm{C} 3 a^{\mathrm{viii}}$ & $4.43(3)$ \\
$\mathrm{C} 4 \cdots \mathrm{C} 4 a^{x}$ & $3.767(17)$ & $\mathrm{C} 4 \cdots \mathrm{C} 4 a^{\mathrm{ix}}$ & $4.051(17)$ \\
\hline
\end{tabular}

Symmetry codes: (v) $x, y+1, z$; (vi) $x-\frac{1}{2}, y+\frac{1}{2}, z$; (vii) $x-\frac{1}{2}, y-\frac{1}{2}, z$; (viii) $-x+1,-y,-z$; (ix) $-x+\frac{3}{2},-y+\frac{1}{2},-z$; (x) $x, y-1, z$; (xi) $x+\frac{1}{2}, y-\frac{1}{2}, z$; (xii) $x+\frac{1}{2}, y+\frac{1}{2}, z$.

[4.05 (2) ̊̊; Stadnicka \& Glazer, 1980] where disorder of the ethyl groups occurs. On the other hand, these intermolecular distances are somewhat longer than in sodium and potassium propanoates, where disorder of the ethyl groups has also been observed (Fábry \& Samolová, 2020). In the latter structures, the distances between two ethyl groups while one of them is in a disordered position are as short as 2.609 (8) and 2.651 (9) $\AA$, respectively, which is an indication of a dynamic disorder: $c f$. the discussion about the disorder in $\mathrm{Ca}_{2} \mathrm{Ba}\left(\mathrm{C}_{3} \mathrm{H}_{5} \mathrm{O}_{2}\right)_{6}$ by Stadnicka \& Glazer (1980) according to whom the disorder is related to close $\mathrm{C}-\mathrm{C}$ distances that are shorter than the sum of the van der Waals radii (about $4.5 \AA$ ). In the structurally related rubidium and caesium propanoates, however, such an occupational disorder does not take place, most probably because of the longer distances between the ethyl groups in the latter structures. The shortest $\mathrm{C}-\mathrm{C}$ distances in rubidium and caesium propanoates are $3.908(12)$ and $3.882(13) \AA$, respectively.

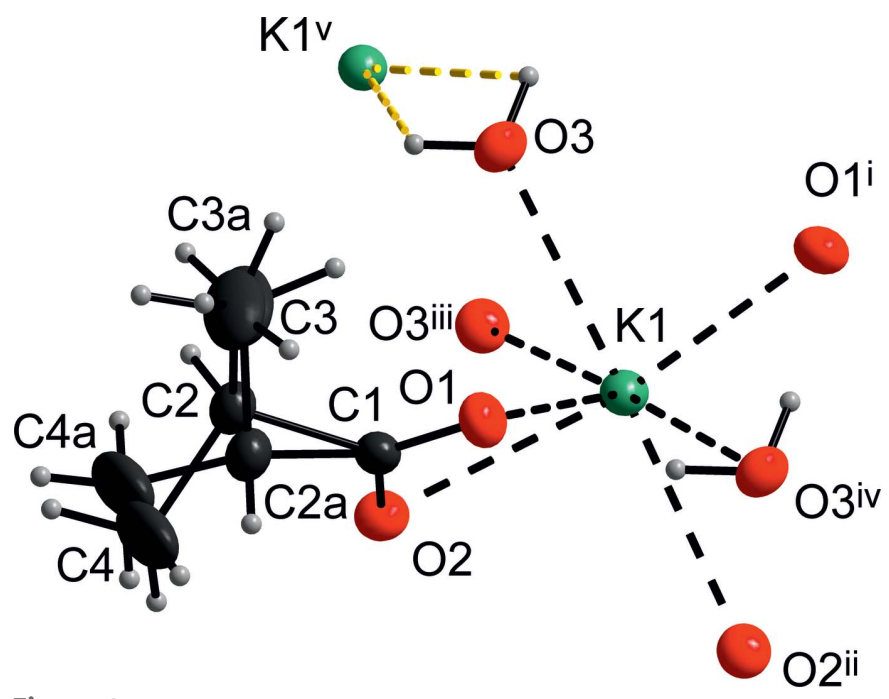

Figure 3

The structural motif showing the interaction of a water molecule to $\mathrm{K} 1^{\mathrm{v}}$. Displacement ellipsoids are shown at the $30 \%$ probability level. The colours are assigned to the atoms are as in Fig. 1. Symmetry codes as in Fig. 1 and (v) $x, 1+y, z$.

\section{Synthesis and crystallization}

Preparation of potassium 2-methylpropanoate was intended. The compound was prepared by dissolving potassium carbonate sesquihydrate $(1.50 \mathrm{~g})$ with 2-methylpropanoic acid $(0.80 \mathrm{~g})$ in the molar ratio $1: 2$ in water. The $\mathrm{pH}$ of the solution was adjusted to $6-7$ by addition of several tenths of a $\mathrm{ml}$ of the acid.

The solution was filtered and the excess amount of water was evaporated at $313 \mathrm{~K}$. Shortly before crystallization, a layer with a pronounced viscosity appeared on the surface of the solution. The crystals grew in the form of elongated colourless plates of several tenths of a $\mathrm{mm}$ in their longest direction.

\section{Structure determination and refinement}

Crystal data, data collection and structure refinement details are summarized in Table 5. The refinement was carried out on the averaged set of independent diffractions. All of the nonhydrogen atoms were determined by SHELXT (Sheldrick, 2015). The structure was treated with consideration of a positional disorder of the methylethyl chain. This disorder was revealed by a relatively high peak of residual electron density $\left(0.68 \mathrm{e} \AA^{-3}\right)$ in the vicinity of atom C2 (Fig. $4 a$ ), which was pertinent to a model without assumed disorder. This residual peak was on the opposite side of the vector $\mathrm{C} 2-\mathrm{H} 1 \mathrm{C} 2$ and was observable in the difference electron-density map using a model without the atoms $\mathrm{C} 2, \mathrm{C} 3$ and $\mathrm{C} 4$ as well as without the hydrogens attached to the latter carbons. This peak was assigned to a disordered atom $\mathrm{C} 2$ and denoted as $\mathrm{C} 2 a$. Correspondingly, the carbon $\mathrm{C} 3$ was also disordered in the difference electron-density map (Fig. $4 b$ ). Atoms C3 and C4 were split into the positions $\mathrm{C} 3, \mathrm{C} 3 a$ and $\mathrm{C} 4, \mathrm{C} 4 a$ after inclusion into the difference electron-density map. (a)

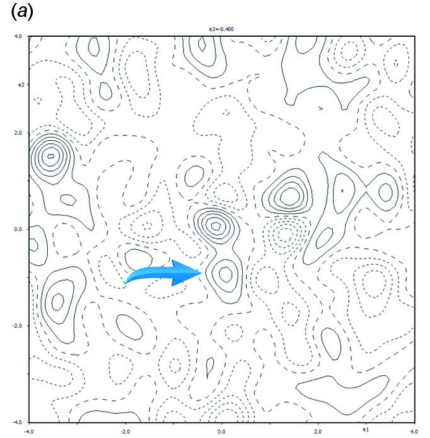

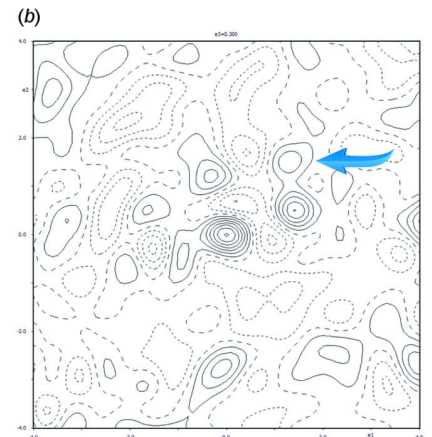

Figure 4

(a) The maximum $(0.6025,0.0146,0.1014)$, which is indicated by the arrow, is in the vicinity of $\mathrm{C} 2$. The increment of positive (solid lines) and

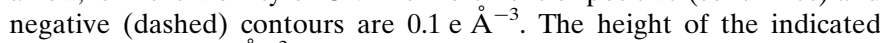
maximum is 0.33 e $\AA^{-3}$ in the depicted section. The structural model did not contain the atoms $\mathrm{C} 2, \mathrm{C} 2 a, \mathrm{C} 3, \mathrm{C} 3 a, \mathrm{C} 4$ and $\mathrm{C} 4 a$ and the attached $\mathrm{H}$ atoms. $(b)$ The maximum $(0.4677,0.5409,0.0940)$, which is indicated by the arrow, is in the vicinity of $\mathrm{C} 3$. The increment of positive (solid lines) and negative (dashed) contours are $0.1 \mathrm{e} \AA^{-3}$. The height of the maximum is $0.27 \mathrm{e}^{-3}$ in the depicted section. The model did not contain the atoms $\mathrm{C} 2, \mathrm{C} 2 a, \mathrm{C} 3, \mathrm{C} 3 a, \mathrm{C} 4$ and $\mathrm{C} 4 a$ and the attached $\mathrm{H}$ atoms. 
Table 5

Experimental details.

Crystal data

Chemical formula

$M_{\mathrm{r}}$

Crystal system, space group

Temperature $(\mathrm{K})$

$a, b, c(\AA)$

$\beta\left({ }^{\circ}\right)$

$V\left(\AA^{3}\right)$

$Z$

Radiation type

$\mu\left(\mathrm{mm}^{-1}\right)$

Crystal size (mm)

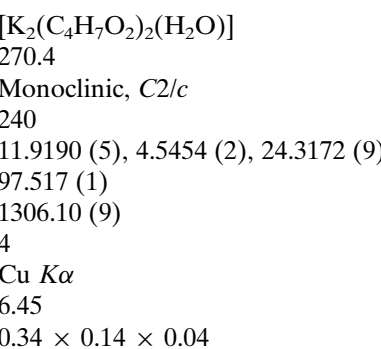

Data collection

Diffractometer

Absorption correction

$T_{\min }, T_{\max }$

No. of measured, independent and observed $[I>3 \sigma(I)]$ reflections

$R_{\text {int }}$

$(\sin \theta / \lambda)_{\max }\left(\AA^{-1}\right)$

Bruker D8 VENTURE Kappa

Duo PHOTON 100 CMOS

Multi-scan (SADABS; Bruker, 2017)

$0.219,0.765$

$10532,1269,1212$

0.036

0.618

Refinement

$R[F>3 \sigma(F)], w R(F), S$

No. of reflections

No. of parameters

No. of restraints

$\mathrm{H}$-atom treatment

$\Delta \rho_{\max }, \Delta \rho_{\min }\left(\mathrm{e} \AA^{-3}\right)$

$0.028,0.082,2.48$
1269
82
9
$\mathrm{H}$ atoms treated by a mixture of
$\quad$ independent and constrained
$\quad$ refinement
$0.19,-0.22$

Computer programs: Instrument Service and SAINT (Bruker, 2017), SHELXT (Sheldrick, 2015), JANA2006 (Petříček et al., 2014) and DIAMOND (Brandenburg, 2015).

The occupational parameters of these pairs of atoms, as well as of the attached hydrogens, were constrained so that their sum is equal to 1; the occupational parameter of atom $\mathrm{C} 4$ was refined. Each pair of these carbon atoms was constrained in such a way that the atom with the minor occupancy was assigned the same displacement parameters as the atom with the major occupancy. The carboxylate carbon $\mathrm{C} 1$ was not split; the present model with the non-split carboxylate carbon $\mathrm{C} 1$ was given preference because a splitting was too small and called for severe restraints of the $\mathrm{C} 1-\mathrm{O} 1$ and $\mathrm{C} 1-\mathrm{O} 2$ distances.

The methanetriyl hydrogens $\mathrm{H} 1 c 2$ and $\mathrm{H} 1 c 2 a$, although observable, were placed in calculated positions. The latter hydrogens were refined under the following constraints: $\mathrm{C}_{\text {methanetriyl }}-\mathrm{H}_{\text {methanetriyl }}=0.99 \AA, \quad U_{\text {iso }}\left(\mathrm{H}_{\text {methanetriyl }}\right)=$ $1.2 U_{\text {eq }}\left(\mathrm{C}_{\text {methanetriyl }}\right)$. Subsequently, after the anisotropic refinement of the non-hydrogen atoms with the methanetriyl hydrogen, the difference electron-density map revealed the methyl hydrogens. All of the methyl hydrogens were discernible in the difference electron-density maps. The hydrogens belonging to the major disorder component were found at first and then, after the refinement had converged, the other methyl hydrogens were found and refined. The methyl hydrogens were refined under the following constraints: $\mathrm{C}_{\text {methyl }}-\mathrm{H}_{\text {methyl }}=0.96 \AA, \quad U_{\text {iso }}\left(\mathrm{H}_{\text {methyl }}\right)=$ $1.5 U_{\text {eq }}\left(\mathrm{C}_{\text {methyl }}\right)$. A following difference electron-density map revealed the water hydrogen, which was situated in a general position in contrast to its carrier O3. The water hydrogen was refined using the angle restraint $\mathrm{H} 1 O 3-\mathrm{O} 3-\mathrm{H} 1 O 3^{\mathrm{i}}$ [symmetry code: (i) $1-x, y, \frac{1}{2}-z$ ] $=105.00(1)^{\circ}$ while $U_{\text {iso }}(\mathrm{H} 1 O 3)=1.5 U_{\text {eq }}(\mathrm{O} 3)$. A trial refinement showed that the water oxygen was fully occupied. The $\mathrm{C} 1-\mathrm{C} 2, \mathrm{C} 1-\mathrm{C} 2 a$ bonds were restrained to be equal [1.540 (1) $\AA$ ] as were $\mathrm{C} 2-\mathrm{C} 3$, $\mathrm{C} 2-\mathrm{C} 3 a$ and $\mathrm{C} 2-\mathrm{C} 4, \mathrm{C} 2-\mathrm{C} 4 a[1.500$ (1) $\AA$ ]. These values were found to yield the lowest $R$ factors. Moreover, angle restraints to $\mathrm{C} 3-\mathrm{C} 2-\mathrm{C} 4$ and $\mathrm{C} 3 a-\mathrm{C} 2 a-\mathrm{C} 4 a$ were also applied. Of course, these $\mathrm{C}-\mathrm{C}$ distances are affected by a large thermal agitation and are less reliable, as are the geometric parameters, compared to those of atom $\mathrm{C} 1$.

\section{Acknowledgements}

Dr Ivana Císařová from the Faculty of Science is thanked for the generous measurement of the sample.

\section{Funding information}

The authors express their gratitude for the support provided by Project NPU I - LO1603 of the Ministry of Education of the Czech Republic to the Institute of Physics of the Academy of Sciences of the Czech Republic.

\section{References}

Bierke, T. \& Meyer, G. (2008). Thesis, Universität zu Köln, Germany. Boyle, T. J., Raymond, R., Boye, D. M., Ottley, L. A. M. \& Lu, P. (2010). Dalton Trans. 39, 8050-8063.

Brandenburg, K. (2005). DIAMOND. Crystal Impact GbR, Bonn, Germany.

Brese, N. E. \& O'Keeffe, M. (1991). Acta Cryst. B47, 192-197.

Bruker (2017). Instrument Service, SAINT and SADABS. Bruker AXS Inc., Madison, Wisconsin, USA.

Coker, E. N., Boyle, T. J., Rodriguez, M. A. \& Alam, T. M. (2004). Polyhedron, 23, 1739-1747.

Dumbleton, J. H. \& Lomer, T. R. (1965). Acta Cryst. 19, 301-307.

Fábry, J. \& Samolová, E. (2020). Acta Cryst. E76, 1508-1513.

Ferloni, P., Sanesi, M. \& Franzosini, P. (1975). Z. Naturforsch. Teil A, 30, 1447-1457.

Fischer, A. I., Gurzhiy, V. V., Aleksandrova, J. V. \& Pakina, M. I. (2017). Acta Cryst. E73, 318-321.

Gilli, G. \& Gilli, P. (2009). The Nature of the Hydrogen Bond: Outline of a comprehensive hydrogen bond theory, p. 61. Oxford University Press.

Groom, C. R., Bruno, I. J., Lightfoot, M. P. \& Ward, S. C. (2016). Acta Cryst. B72, 171-179.

Heyman, J. B., Chen, C.-H. \& Foxman, B. M. (2020). Cryst. Growth Des. 20, 330-336.

Ilina, E. G., Troyanov, S. I. \& Dunaeva, K. M. (1992). Koord. Khim. 18, 882-890.

Kotal, A., Paira, T. K., Banerjee, S. \& Mandal, T. K. (2010). Langmuir, 26, 6576-6582.

Malaestean, I. L., Ellern, A., Baca, S. \& Kögerler, P. (2012). Chem. Commun. 48, 1499-1501.

Malaestean, I. L., Ellern, A. \& Kögerler, P. (2013a). Eur. J. Inorg. Chem., pp. 1635-1638.

Malaestean, I. L., Schmitz, S., Ellern, A. \& Kögerler, P. (2013b). Acta Cryst. C69, 1144-1146.

Malaestean, I. L., Speldrich, M., Ellern, A., Baca, S. G., Ward, M. \& Kögerler, P. (2009). Eur. J. Inorg. Chem. pp. 4209-4212.

Martínez Casado, F. J., Ramos Riesco, M., da Silva, I., Labrador, A., Redondo, M. I., García Pérez, M. V., López-Andrés, S. \& 
Rodríguez Cheda, J. A. (2010). J. Phys. Chem. B114, 1007510085.

Martínez Casado, F. J., Riesco, M. R., García Pérez, M. V., Redondo, M. I., López-Andrés, S. \& Rodríguez Cheda, J. A. (2009). J. Phys. Chem. B, 113, 12896-12902.

Mirnaya, T. A., Polishchuk, A. P., Molochaeva, V. I. \& Tolochko, A. S. (1991). Kristallografiya, 36, 377-383.

Petř́íček, V., Dušek, M. \& Palatinus, L. (2014). Z. Kristallogr. 229, 345-352.
Sheldrick, G. M. (2015). Acta Cryst. A71, 3-8.

Skelton, B. W. \& Deacon, G. B. (2017). CSD Communication (refcodes KELKOE, MECVAU). CCDC, Cambridge, England.

Stadnicka, K. \& Glazer, A. M. (1980). Acta Cryst. B36, $2977-$ 2985.

Troyanov, S. I., Mitrofanova, N. D. \& Gorbacheva, M. V. (1993). Koord. Khim. 19, 868-870.

Yuranov, I. A. \& Dunaeva, K. M. (1989). Koord. Khim. 15, 845-847. 


\section{supporting information}

Acta Cryst. (2020). E76, 1669-1674 [https://doi.org/10.1107/S2056989020012591]

Crystal structure of poly $\left[\mu\right.$-aqua-bis $\left(\mu_{3}-2\right.$-methylpropanoato$\left.\kappa^{4} O: O, O^{\prime}: O^{\prime}\right)$ dipotassium]

\section{Jan Fábry and Erika Samolová}

Computing details

Data collection: Instrument Service (Bruker, 2017); cell refinement: SAINT (Bruker, 2017); data reduction: SAINT (Bruker, 2017); program(s) used to solve structure: SHELXT (Sheldrick, 2015); program(s) used to refine structure: JANA2006 (Petř́íček et al., 2014); molecular graphics: DIAMOND (Brandenburg, 2015); software used to prepare material for publication: JANA2006 (Petrríček et al., 2014).

Poly $\left[\mu\right.$-aqua-bis $\left(\mu_{3}-2\right.$-methylpropanoato- $\left.\left.\kappa^{4} \mathrm{O}: \mathrm{O}</ \mathrm{i}\right), \mathrm{O}^{\prime}: \mathrm{O}^{\prime}\right)$ dipotassium $]$

\section{Crystal data}

$\left[\mathrm{K}_{2}\left(\mathrm{C}_{4} \mathrm{H}_{7} \mathrm{O}_{2}\right)_{2}\left(\mathrm{H}_{2} \mathrm{O}\right)\right]$

$M_{r}=270.4$

Monoclinic, $C 2 / c$

Hall symbol: $-\mathrm{C} 2 \mathrm{yc}$

$a=11.9190(5) \AA$

$b=4.5454(2) \AA$

$c=24.3172(9) \AA$

$\beta=97.517(1)^{\circ}$

$V=1306.10(9) \AA^{3}$

$Z=4$

$F(000)=568$

\section{Data collection}

Bruker D8 VENTURE Kappa Duo PHOTON 100 CMOS diffractometer

Radiation source: $\mathrm{I} \mu \mathrm{S}$ micro-focus sealed tube Helios $\mathrm{Cu}$ multilayer optic monochromator $\varphi$ and $\omega$ scans

Absorption correction: multi-scan

(SADABS; Bruker, 2017)

$T_{\min }=0.219, T_{\max }=0.765$

Refinement

Refinement on $F^{2}$

$R[F>3 \sigma(F)]=0.028$

$w R(F)=0.082$

$S=2.48$

1269 reflections

82 parameters
There have been used diffractions with $\mathrm{I} / \sigma(\mathrm{I})>20$

for the unit cell determination.

$D_{\mathrm{x}}=1.375 \mathrm{Mg} \mathrm{m}^{-3}$

$\mathrm{Cu} K \alpha$ radiation, $\lambda=1.54178 \AA$

Cell parameters from 8438 reflections

$\theta=7.4-72.2^{\circ}$

$\mu=6.45 \mathrm{~mm}^{-1}$

$T=240 \mathrm{~K}$

Plate, colourless

$0.34 \times 0.14 \times 0.04 \mathrm{~mm}$

10532 measured reflections

1269 independent reflections

1212 reflections with $I>3 \sigma(I)$

$R_{\text {int }}=0.036$

$\theta_{\max }=72.2^{\circ}, \theta_{\min }=7.4^{\circ}$

$h=-14 \rightarrow 14$

$k=-5 \rightarrow 5$

$l=-30 \rightarrow 30$
9 restraints

94 constraints

Primary atom site location: dual

$\mathrm{H}$ atoms treated by a mixture of independent and constrained refinement 
Weighting scheme based on measured s.u.'s $w=$ $1 /\left(\sigma^{2}(I)+0.0004 I^{2}\right)$

$(\Delta / \sigma)_{\max }=0.035$
$\Delta \rho_{\max }=0.19$ e $\AA^{-3}$
$\Delta \rho_{\min }=-0.22$ e $\AA^{-3}$

Special details

Refinement. The reflections $220,420,517$ and 330 were excluded from the refinement because $\left|\mathrm{I}_{\mathrm{obs}}-\mathrm{I}_{\text {calc }}\right|>15 \sigma\left(\mathrm{I}_{\mathrm{obs}}\right)$.

Fractional atomic coordinates and isotropic or equivalent isotropic displacement parameters $\left(\AA^{2}\right)$

\begin{tabular}{llllll}
\hline & $x$ & $y$ & $z$ & $U_{\text {iso }} / U_{\text {eq }}$ & Occ. $(<1)$ \\
\hline K1 & $0.65739(3)$ & $0.08834(7)$ & $0.292673(13)$ & $0.03769(13)$ & \\
O1 & $0.54092(11)$ & $-0.0749(2)$ & $0.17459(5)$ & $0.0474(4)$ & \\
O2 & $0.71739(10)$ & $0.0879(2)$ & $0.18489(5)$ & $0.0451(4)$ & \\
O3 & 0.5 & $0.5048(4)$ & 0.25 & $0.0442(5)$ & \\
H1o3 & $0.521(2)$ & $0.616(3)$ & $0.2262(8)$ & $0.0664^{*}$ & \\
C1 & $0.62018(14)$ & $0.0693(3)$ & $0.15869(6)$ & $0.0357(4)$ & \\
C2 & $0.59779(18)$ & $0.2545(5)$ & $0.10542(7)$ & $0.0445(6)$ & $0.801(3)$ \\
H1c2 & 0.62015 & 0.458674 & 0.115969 & $0.0533^{*}$ & $0.801(3)$ \\
C2a & $0.5957(9)$ & $0.124(2)$ & $0.09573(13)$ & $0.0445(6)$ & $0.199(3)$ \\
H1c2a & 0.590888 & -0.055688 & 0.072613 & $0.0533^{*}$ & $0.199(3)$ \\
C3 & $0.4752(2)$ & $0.2726(12)$ & $0.0811(2)$ & $0.0828(14)$ & $0.801(3)$ \\
H1c3 & 0.433861 & 0.380314 & 0.105886 & $0.1242^{*}$ & $0.801(3)$ \\
H2c3 & 0.468892 & 0.371338 & 0.045975 & $0.1242^{*}$ & $0.801(3)$ \\
H3c3 & 0.444536 & 0.077688 & 0.076086 & $0.1242^{*}$ & $0.801(3)$ \\
C3a & $0.4876(10)$ & $0.297(4)$ & $0.0912(13)$ & $0.0828(14)$ & $0.199(3)$ \\
H1c3a & 0.442774 & 0.254928 & 0.056368 & $0.1242^{*}$ & $0.199(3)$ \\
H2c3a & 0.44613 & 0.243332 & 0.120994 & $0.1242^{*}$ & $0.199(3)$ \\
H3c3a & 0.504672 & 0.50346 & 0.093401 & $0.1242^{*}$ & $0.199(3)$ \\
C4 & $0.6678(4)$ & $0.1371(12)$ & $0.06307(12)$ & $0.1008(19)$ & $0.801(3)$ \\
H1c4 & 0.743884 & 0.103888 & 0.080315 & $0.1512^{*}$ & $0.801(3)$ \\
H2c4 & 0.635891 & -0.044833 & 0.048302 & $0.1512^{*}$ & $0.801(3)$ \\
H3c4 & 0.668259 & 0.277338 & 0.033579 & $0.1512^{*}$ & $0.801(3)$ \\
C4a & $0.6882(11)$ & $0.314(4)$ & $0.0786(7)$ & $0.1008(19)$ & $0.199(3)$ \\
H1c4a & 0.669733 & 0.367954 & 0.040336 & $0.1512^{*}$ & $0.199(3)$ \\
H2c4a & 0.695838 & 0.487804 & 0.101114 & $0.1512^{*}$ & $0.199(3)$ \\
H3c4a & 0.758165 & 0.20639 & 0.083389 & $0.1512^{*}$ & $0.199(3)$ \\
& & & & & \\
& & & & &
\end{tabular}

Atomic displacement parameters $\left(\AA^{2}\right)$

\begin{tabular}{lllllll}
\hline & $U^{11}$ & $U^{22}$ & $U^{33}$ & $U^{12}$ & $U^{13}$ & $U^{23}$ \\
\hline $\mathrm{K} 1$ & $0.0335(2)$ & $0.0384(2)$ & $0.0413(2)$ & $0.00132(11)$ & $0.00537(14)$ & $0.00039(11)$ \\
O1 & $0.0463(7)$ & $0.0488(7)$ & $0.0492(7)$ & $-0.0052(5)$ & $0.0138(5)$ & $0.0043(5)$ \\
O2 & $0.0387(6)$ & $0.0496(6)$ & $0.0457(7)$ & $0.0038(5)$ & $0.0002(5)$ & $0.0011(4)$ \\
O3 & $0.0510(10)$ & $0.0318(7)$ & $0.0490(9)$ & 0 & $0.0031(7)$ & 0 \\
C1 & $0.0375(8)$ & $0.0359(7)$ & $0.0345(8)$ & $0.0047(6)$ & $0.0075(6)$ & $-0.0002(5)$ \\
C2 & $0.0494(10)$ & $0.0422(12)$ & $0.0417(10)$ & $0.0012(11)$ & $0.0056(8)$ & $0.0081(9)$ \\
C2a & $0.0494(10)$ & $0.0422(12)$ & $0.0417(10)$ & $0.0012(11)$ & $0.0056(8)$ & $0.0081(9)$ \\
C3 & $0.0537(14)$ & $0.127(3)$ & $0.061(3)$ & $0.0035(16)$ & $-0.0173(15)$ & $0.0378(19)$
\end{tabular}




\begin{tabular}{lllllll} 
C3a & $0.0537(14)$ & $0.127(3)$ & $0.061(3)$ & $0.0035(16)$ & $-0.0173(15)$ & $0.0378(19)$ \\
C4 & $0.109(3)$ & $0.155(5)$ & $0.0460(19)$ & $0.053(3)$ & $0.038(2)$ & $0.029(2)$ \\
C4a & $0.109(3)$ & $0.155(5)$ & $0.0460(19)$ & $0.053(3)$ & $0.038(2)$ & $0.029(2)$ \\
\hline
\end{tabular}

Geometric parameters $\left(\AA,{ }^{\circ}\right)$

\begin{tabular}{|c|c|c|c|}
\hline $\mathrm{K} 1-\mathrm{O} 1$ & $3.1113(13)$ & $\mathrm{C} 2-\mathrm{C} 4$ & $1.505(4)$ \\
\hline $\mathrm{K} 1-\mathrm{O} 1^{\mathrm{i}}$ & $2.6951(14)$ & $\mathrm{C} 2 \mathrm{a}-\mathrm{H} 1 \mathrm{c} 2 \mathrm{a}$ & 0.99 \\
\hline $\mathrm{K} 1-\mathrm{O} 2$ & $2.8056(13)$ & $\mathrm{C} 2 \mathrm{a}-\mathrm{C} 4 \mathrm{a}$ & $1.500(18)$ \\
\hline $\mathrm{K} 1-\mathrm{O} 2^{\mathrm{ii}}$ & $2.7360(12)$ & $\mathrm{C} 3-\mathrm{H} 1 \mathrm{c} 3$ & 0.96 \\
\hline $\mathrm{K} 1-\mathrm{O} 2^{\mathrm{iii}}$ & $2.7330(12)$ & $\mathrm{C} 3-\mathrm{H} 2 \mathrm{c} 3$ & 0.96 \\
\hline $\mathrm{K} 1-\mathrm{O} 3^{\mathrm{iv}}$ & $3.3351(13)$ & $\mathrm{C} 3-\mathrm{H} 3 \mathrm{c} 3$ & 0.96 \\
\hline $\mathrm{K} 1-\mathrm{O} 3$ & $2.7693(12)$ & $\mathrm{C} 3 \mathrm{a}-\mathrm{H} 1 \mathrm{c} 3 \mathrm{a}$ & 0.96 \\
\hline $\mathrm{O} 1-\mathrm{C} 1$ & $1.252(2)$ & $\mathrm{C} 3 \mathrm{a}-\mathrm{H} 2 \mathrm{c} 3 \mathrm{a}$ & 0.96 \\
\hline $\mathrm{O} 2-\mathrm{C} 1$ & $1.2499(19)$ & $\mathrm{C} 3 a-\mathrm{H} 3 \mathrm{c} 3 \mathrm{a}$ & 0.96 \\
\hline $\mathrm{O} 3-\mathrm{H} 1 \mathrm{o} 3$ & $0.83(2)$ & $\mathrm{C} 4-\mathrm{H} 1 \mathrm{c} 4$ & 0.96 \\
\hline $\mathrm{O} 3-\mathrm{H} 1 \mathrm{o} 3^{\mathrm{i}}$ & $0.83(2)$ & $\mathrm{C} 4-\mathrm{H} 2 \mathrm{c} 4$ & 0.96 \\
\hline $\mathrm{C} 1-\mathrm{C} 2$ & $1.539(2)$ & $\mathrm{C} 4-\mathrm{H} 3 \mathrm{c} 4$ & 0.96 \\
\hline $\mathrm{C} 1-\mathrm{C} 2 \mathrm{a}$ & $1.541(4)$ & $\mathrm{C} 4 \mathrm{a}-\mathrm{H} 1 \mathrm{c} 4 \mathrm{a}$ & 0.96 \\
\hline $\mathrm{C} 2-\mathrm{C} 3$ & $1.505(4)$ & $\mathrm{C} 4 \mathrm{a}-\mathrm{H} 2 \mathrm{c} 4 \mathrm{a}$ & 0.96 \\
\hline $\mathrm{C} 2-\mathrm{C} 3 \mathrm{a}$ & $1.328(13)$ & $\mathrm{C} 4 \mathrm{a}-\mathrm{H} 3 \mathrm{c} 4 \mathrm{a}$ & 0.96 \\
\hline $\mathrm{O} 1-\mathrm{K} 1-\mathrm{O} 1^{\mathrm{i}}$ & $84.51(4)$ & $\mathrm{O} 2-\mathrm{C} 1-\mathrm{C} 2 \mathrm{a}$ & $122.5(4)$ \\
\hline $\mathrm{O} 1-\mathrm{K} 1-\mathrm{O} 2$ & $43.54(3)$ & $\mathrm{C} 1-\mathrm{C} 2-\mathrm{H} 1 \mathrm{c} 2$ & 106.47 \\
\hline $\mathrm{O} 1-\mathrm{K} 1-\mathrm{O} 2^{\mathrm{ii}}$ & $98.72(3)$ & $\mathrm{C} 1-\mathrm{C} 2-\mathrm{C} 3$ & $114.4(2)$ \\
\hline $\mathrm{O} 1-\mathrm{K} 1-\mathrm{O} 2^{\mathrm{iii}}$ & $123.27(4)$ & $\mathrm{C} 1-\mathrm{C} 2-\mathrm{C} 4$ & $109.3(2)$ \\
\hline $\mathrm{O} 1-\mathrm{K} 1-\mathrm{O} 3^{\mathrm{iv}}$ & $50.08(2)$ & $\mathrm{H} 1 \mathrm{c} 2-\mathrm{C} 2-\mathrm{C} 3$ & 105.38 \\
\hline $\mathrm{O} 1-\mathrm{K} 1-\mathrm{O} 3$ & $67.58(3)$ & $\mathrm{H} 1 \mathrm{c} 2-\mathrm{C} 2-\mathrm{C} 4$ & 110.8 \\
\hline $\mathrm{O} 1-\mathrm{i}-\mathrm{K} 1-\mathrm{O} 2$ & $128.05(4)$ & $\mathrm{C} 3-\mathrm{C} 2-\mathrm{C} 4$ & $110.4(3)$ \\
\hline 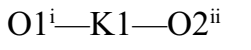 & $100.88(4)$ & $\mathrm{H} 1 \mathrm{c} 2 \mathrm{a}-\mathrm{C} 2 \mathrm{a}-\mathrm{C} 3 \mathrm{a}$ & 113.92 \\
\hline 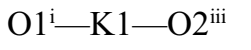 & $130.31(4)$ & $\mathrm{H} 1 \mathrm{c} 2 \mathrm{a}-\mathrm{C} 2 \mathrm{a}-\mathrm{C} 4 \mathrm{a}$ & 107.85 \\
\hline 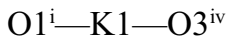 & $52.67(3)$ & $\mathrm{C} 3 \mathrm{a}-\mathrm{C} 2 \mathrm{a}-\mathrm{C} 4 \mathrm{a}$ & $109.5(12)$ \\
\hline 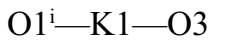 & $73.84(3)$ & $\mathrm{C} 2-\mathrm{C} 3-\mathrm{H} 1 \mathrm{c} 3$ & 109.47 \\
\hline $\mathrm{O} 2-\mathrm{K} 1-\mathrm{O} 2^{\mathrm{ii}}$ & $89.24(4)$ & $\mathrm{C} 2-\mathrm{C} 3-\mathrm{H} 2 \mathrm{c} 3$ & 109.47 \\
\hline $\mathrm{O} 2-\mathrm{K} 1-\mathrm{O} 2^{\mathrm{iii}}$ & $89.30(4)$ & $\mathrm{C} 2-\mathrm{C} 3-\mathrm{H} 3 \mathrm{c} 3$ & 109.47 \\
\hline $\mathrm{O} 2-\mathrm{K} 1-\mathrm{O} 3^{\text {iv }}$ & $84.87(2)$ & $\mathrm{H} 1 \mathrm{c} 3-\mathrm{C} 3-\mathrm{H} 2 \mathrm{c} 3$ & 109.47 \\
\hline $\mathrm{O} 2-\mathrm{K} 1-\mathrm{O} 3$ & $83.88(2)$ & $\mathrm{H} 1 \mathrm{c} 3-\mathrm{C} 3-\mathrm{H} 3 \mathrm{c} 3$ & 109.47 \\
\hline 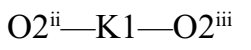 & $112.43(4)$ & $\mathrm{H} 2 \mathrm{c} 3-\mathrm{C} 3-\mathrm{H} 3 \mathrm{c} 3$ & 109.47 \\
\hline 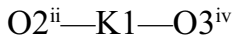 & $70.78(3)$ & $\mathrm{C} 2 \mathrm{a}-\mathrm{C} 3 \mathrm{a}-\mathrm{H} 1 \mathrm{c} 3 \mathrm{a}$ & 109.47 \\
\hline $\mathrm{O} 2{ }^{\mathrm{ii}}-\mathrm{K} 1-\mathrm{O} 3$ & $165.48(4)$ & $\mathrm{C} 2 \mathrm{a}-\mathrm{C} 3 \mathrm{a}-\mathrm{H} 2 \mathrm{c} 3 \mathrm{a}$ & 109.47 \\
\hline 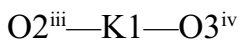 & $173.34(3)$ & $\mathrm{C} 2 \mathrm{a}-\mathrm{C} 3 \mathrm{a}-\mathrm{H} 3 \mathrm{c} 3 \mathrm{a}$ & 109.47 \\
\hline $\mathrm{O} 2{ }^{\mathrm{iii}}-\mathrm{K} 1-\mathrm{O} 3$ & $80.35(4)$ & $\mathrm{H} 1 \mathrm{c} 3 \mathrm{a}-\mathrm{C} 3 \mathrm{a}-\mathrm{H} 2 \mathrm{c} 3 \mathrm{a}$ & 109.47 \\
\hline $\mathrm{O}^{\mathrm{iv}}-\mathrm{K} 1-\mathrm{O} 3$ & $95.81(3)$ & $\mathrm{H} 1 \mathrm{c} 3 \mathrm{a}-\mathrm{C} 3 \mathrm{a}-\mathrm{H} 3 \mathrm{c} 3 \mathrm{a}$ & 109.47 \\
\hline $\mathrm{K} 1-\mathrm{O} 1-\mathrm{K} 1^{\mathrm{i}}$ & $87.96(4)$ & $\mathrm{H} 2 \mathrm{c} 3 \mathrm{a}-\mathrm{C} 3 \mathrm{a}-\mathrm{H} 3 \mathrm{c} 3 \mathrm{a}$ & 109.47 \\
\hline $\mathrm{K} 1-\mathrm{O} 2-\mathrm{K} 1^{\mathrm{ii}}$ & $90.76(4)$ & $\mathrm{C} 2-\mathrm{C} 4-\mathrm{H} 1 \mathrm{c} 4$ & 109.47 \\
\hline $\mathrm{K} 1-\mathrm{O} 2-\mathrm{K} 1^{\mathrm{iii}}$ & $90.70(4)$ & $\mathrm{C} 2-\mathrm{C} 4-\mathrm{H} 2 \mathrm{c} 4$ & 109.47 \\
\hline $\mathrm{K} 1^{\mathrm{ii}}-\mathrm{O} 2-\mathrm{K} 1^{\mathrm{iii}}$ & $112.43(4)$ & $\mathrm{C} 2-\mathrm{C} 4-\mathrm{H} 3 \mathrm{c} 4$ & 109.47 \\
\hline $\mathrm{K} 1-\mathrm{O} 3-\mathrm{K} 1^{\mathrm{v}}$ & $95.806(12)$ & $\mathrm{H} 1 \mathrm{c} 4-\mathrm{C} 4-\mathrm{H} 2 \mathrm{c} 4$ & 109.47 \\
\hline
\end{tabular}


supporting information

$\begin{array}{llll}\mathrm{K} 1-\mathrm{O} 3-\mathrm{K}^{\mathrm{i}} & 93.77(5) & \mathrm{H} 1 \mathrm{c} 4-\mathrm{C} 4-\mathrm{H} 3 \mathrm{c} 4 & 109.47 \\ \mathrm{~K} 1-\mathrm{O} 3-\mathrm{K}^{\mathrm{vi}} & 170.43(4) & \mathrm{H} 2 \mathrm{c} 4-\mathrm{C} 4-\mathrm{H} 3 \mathrm{c} 4 & 109.47 \\ \mathrm{~K} 1{ }^{\mathrm{v}}-\mathrm{O} 3-\mathrm{K} 1^{\mathrm{i}} & 170.43(4) & \mathrm{H} 1 \mathrm{c} 2-\mathrm{C} 4 \mathrm{a}-\mathrm{C} 2 \mathrm{a} & 66.18 \\ \mathrm{~K}^{\mathrm{v}}-\mathrm{O} 3-\mathrm{K} 1^{\mathrm{vi}} & 74.62(3) & \mathrm{C} 2 \mathrm{a}-\mathrm{C} 4 \mathrm{a}-\mathrm{H} 1 \mathrm{c} 4 \mathrm{a} & 109.47 \\ \mathrm{~K} 1^{\mathrm{i}}-\mathrm{O} 3-\mathrm{K} 1^{\mathrm{vi}} & 95.806(12) & \mathrm{C} 2 \mathrm{a}-\mathrm{C} 4 \mathrm{a}-\mathrm{H} 2 \mathrm{c} 4 \mathrm{a} & 109.47 \\ \mathrm{H} 1 \mathrm{o} 3-\mathrm{O} 3-\mathrm{H} 13^{\mathrm{i}} & 105.0(16) & \mathrm{C} 2 \mathrm{a}-\mathrm{C} 4 \mathrm{a}-\mathrm{H} 3 \mathrm{c} 4 \mathrm{a} & 109.47 \\ \mathrm{O} 1-\mathrm{C} 1-\mathrm{O} 2 & 124.40(13) & \mathrm{H} 1 \mathrm{c} 4 \mathrm{a}-\mathrm{C} 4 \mathrm{a}-\mathrm{H} 2 \mathrm{c} 4 \mathrm{a} & 109.47 \\ \mathrm{O} 1-\mathrm{C} 1-\mathrm{C} 2 & 119.45(14) & \mathrm{H} 1 \mathrm{c} 4 \mathrm{a}-\mathrm{C} 4 \mathrm{a}-\mathrm{H} 3 \mathrm{c} 4 \mathrm{a} & 109.47 \\ \mathrm{O} 1-\mathrm{C} 1-\mathrm{C} 2 \mathrm{a} & 109.8(4) & \mathrm{H} 2 \mathrm{c} 4 \mathrm{a}-\mathrm{C} 4 \mathrm{a}-\mathrm{H} 3 \mathrm{c} 4 \mathrm{a} & 109.47 \\ \mathrm{O} 2-\mathrm{C} 1-\mathrm{C} 2 & 116.04(14) & & \end{array}$

Symmetry codes: (i) $-x+1, y,-z+1 / 2$; (ii) $-x+3 / 2, y-1 / 2,-z+1 / 2$; (iii) $-x+3 / 2, y+1 / 2,-z+1 / 2$; (iv) $x, y-1, z$; (v) $x, y+1, z$; (vi) $-x+1, y+1,-z+1 / 2$.

Hydrogen-bond geometry $\left(\AA,{ }^{\circ}\right)$

\begin{tabular}{lllll}
\hline$D-\mathrm{H} \cdots A$ & $D-\mathrm{H}$ & $\mathrm{H} \cdots A$ & $D \cdots A$ & $D-\mathrm{H} \cdots A$ \\
\hline $\mathrm{O}^{-}-\mathrm{H}_{1 O 3} \cdots \mathrm{O}^{\mathrm{v}}$ & $0.83(2)$ & $1.92(2)$ & $2.7358(17)$ & $167(2)$ \\
$\mathrm{O}^{\mathrm{v}}-\mathrm{H} 1 \mathrm{O} 3{ }^{\mathrm{i} \cdots \mathrm{O} 1^{\mathrm{vi}}}$ & $0.83(2)$ & $1.92(2)$ & $2.7358(17)$ & $167(2)$ \\
\hline
\end{tabular}

Symmetry codes: (i) $-x+1, y,-z+1 / 2$; (v) $x, y+1, z$; (vi) $-x+1, y+1,-z+1 / 2$. 